\title{
Intramedullary neurenteric cyst associated with a tethered spinal cord: Case report and literature review
}

\author{
Jay A. Vachhani, Daniel R. Fassett \\ Department of Neurosurgery, Illinois Neurological Institute, University of Illinois College of Medicine, Peoria, Illinois \\ E-mail: *Jay A.Vachhani - jay.vachhani@gmail.com; Daniel R. Fassett - danfassett@gmail.com \\ *Corresponding author
}

Received:04 May $12 \quad$ Accepted: 15 June $12 \quad$ Published: 14 July 12

This article may be cited as:

Vachhani JA, Fassett DR. Intramedullary neurenteric cyst associated with a tethered spinal cord: Case report and literature review. Surg Neurol Int 20I2;3:80.

Available FREE in open access from: http://www.surgicalneurologyint.com/text.asp?2012/3///80/98525

Copyright: @ 2012 Vachhani JA. This is an open-access article distributed under the terms of the Creative Commons Attribution License, which permits unrestricted use, distribution, and reproduction in any medium, provided the original author and source are credited.

\begin{abstract}
Background: Neurenteric cysts are benign tumors of the central nervous system (CNS) that represent $0.3 \%$ to $0.5 \%$ of all spinal cord tumors. They are usually extramedullary and found in the lower cervical and thoracic spine. Only $12.2 \%$ of neurenteric cysts are documented to be intramedullary.

Case Description: The authors report a case of a 35-year-old female that presented with progressive weakness and loss of coordination in her legs. Magnetic resonance imaging (MRI) showed an intramedullary cystic lesion in the thoracolumbar region and a low-lying conus medullaris suggesting tethered cord. The patient was taken to the operating room for detethering of her spinal cord and resection of the lesion. Pathologic examination of the tissue confirmed the diagnosis of a neurenteric cyst.

Conclusion: A search of the literature since the advent of MRI showed 29 published cases of intramedullary neurentic cysts. Of the 24 published cases with a follow-up $\mathrm{MRI}$, the average recurrence rate was $25 \%$ with a mean follow up of 51 months.
\end{abstract}

Key Words: Intramedullary, neurenteric cyst, tethered spinal cord

\begin{tabular}{|l|}
\hline \multicolumn{1}{|c|}{$\begin{array}{c}\text { Access this article } \\
\text { online }\end{array}$} \\
\hline Website: \\
www.surgicalneurologyint.com \\
\hline DOI: \\
10.4103/2152-7806.98525 \\
\hline \begin{tabular}{l} 
Quick Response Code: \\
\hline
\end{tabular} \\
\hline
\end{tabular}

\section{INTRODUCTION}

Neurenteric cysts, also known as enterogenous cysts or endodermal cysts, are benign tumors of the central nervous system (CNS) which are thought to represent $0.3 \%$ to $1.3 \%$ of all spinal cord tumors. ${ }^{[15,23]}$ They are the result of inappropriate partitioning of the embryonic notocordal plate and presumptive endoderm during the third week of human development. ${ }^{[23]}$ The cysts are lined by nonciliated epithelium that is simple or pseudostratified and cuboidal or columnar. ${ }^{[5]}$ They are found to have a male predominance $(60.4 \%)$ and present at a mean age of 6.4 years in the pediatric population ${ }^{[6]}$ and in the second or third decades of life in the adult population. ${ }^{[23]}$ The embryological origin is thought to be from an abnormal communication between the primitive neurenteric canal, notocord, and neural tube to the adjacent endoderm and mesenchyme during the third week of embryogenesis. ${ }^{[15]}$

Since the advent of magnetic resonance imaging (MRI), it has become possible to diagnose these lesions preoperatively. On T2-weighted imaging, the cysts are hyperintense and display minimal or no enhancement on Tl postcontrast imaging. Typically, the cysts are intradural/extramedullary (78.6\%) and usually arise from the cervical, cervicothoraric, and thoracic spine (73.6\%). ${ }^{[6]}$

This case is unique because the patient presented at the age of 35 with an intramedullary neurenteric cyst in the thoracolumbar spine and a tethered spinal cord. In 
[Downloaded free from http://www.surgicalneurologyint.com on Monday, January 28, 2013, IP: 131.193.153.56] || Click here to download free Android application fo this journal

this paper, we will discuss the treatment of this patient as well as a review of all published literature on patients with intramedullary neurenteric cysts since the advent of MRI.

\section{CASE REPORT}

\section{Presentation}

A 35-year-old female presented with weakness in both legs and loss of coordination over the last year. She had some numbness and burning from her feet to her knees bilaterally and intermittent episodes of bladder incontinence.

\section{Examination}

On examination, she had no cranial nerve deficits and strength and sensation were normal in both upper extremities. She had bilateral lower extremity weakness, grade $3 / 5$ in both dorsiflexors, and 4/5 in all other muscle groups. Her reflexes were $1+$ at the knees and ankles with a very wide-based antalgic gait.

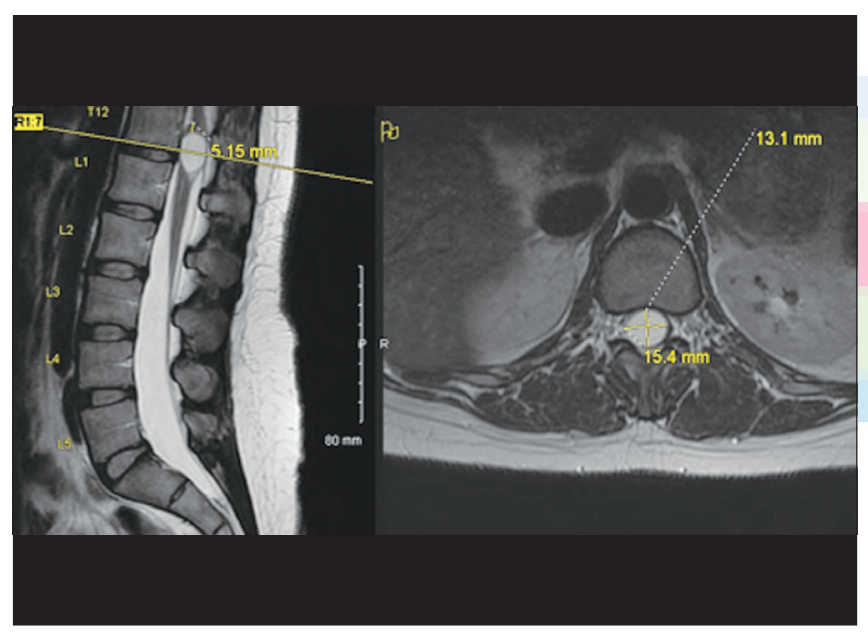

Figure I:T2 sagittal and axial

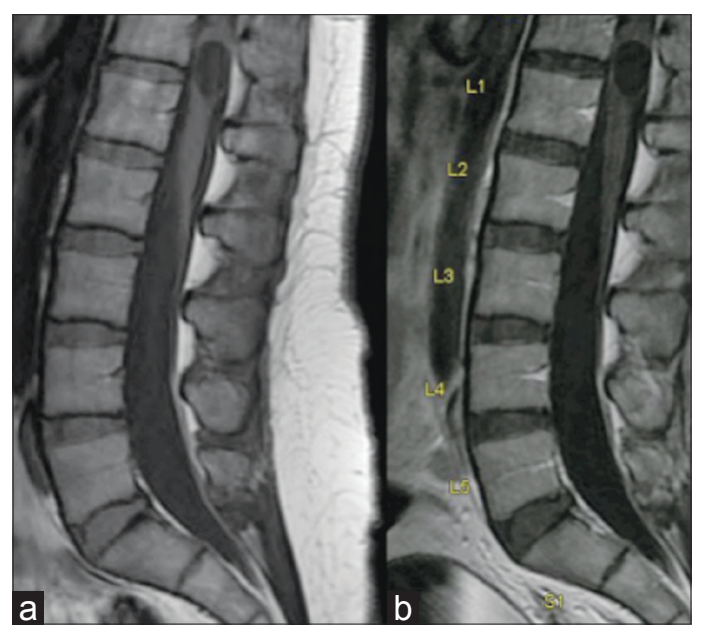

Figure 2:TI sagittal precontrast (a) and postcontrast (b)
Imaging characteristics

MRI of the spine was performed which showed a cystic dilation of her distal cord near T12-Ll that had a similar intensity to cerebrospinal fluid (CSF) and no contrast enhancement. The cord also appeared to be low lying and terminated at the level of L3 [Figures 1 and 2].

\section{Operation}

A laminectomy was performed from $\mathrm{Tl} 1$ to $\mathrm{Ll}$ and $\mathrm{L} 5$ to S1. Initial attention was focused at the L5-Sl level where an intradural dissection was performed and the filum terminale was indentified, cauterized, and sectioned. After release of the tethered cord, the dura was opened from Tll to Ll and the spinal cord was visualized with an intraoperative microscope. A midline myelotomy was performed and a firm capsule was encountered within the cord. The cyst capsule was incised to internally decompress the cyst and allow for resection while minimizing trauma to the normal surrounding spinal cord. A milky white fluid was expressed upon opening the cyst. Microsurgical resection of the cyst capsule was performed while closely monitoring motor evoked potentials (MEP) and somatosenory evoked potentials (SSEP). A large portion of the cyst wall was resected, but a complete resection was aborted after an $80 \%$ decrease in MEP.

\section{Postoperative course}

The patient awoke with increased weakness, in comparison to her preoperative exam, with $2 / 5$ hip flexors, 3/5 knee extensors, 1/5 knee flexors, and absent dorsiflexors, and plantar flexors. Her neurological function gradually improved over the next four weeks. With rehabilitation, her strength and coordination improved with the exception of her left dorsiflexors, which remained $3 / 5$ strength.

\section{Pathological examination}

Hematoxylin and eosin staining revealed multiple irregular cystic spaces lined by epithelium [Figure 3]. Most areas showed simple or stratified cuboidal cells, but some areas had a squamous appearance. Immunohistochemical stains were reactive for pankeratin,

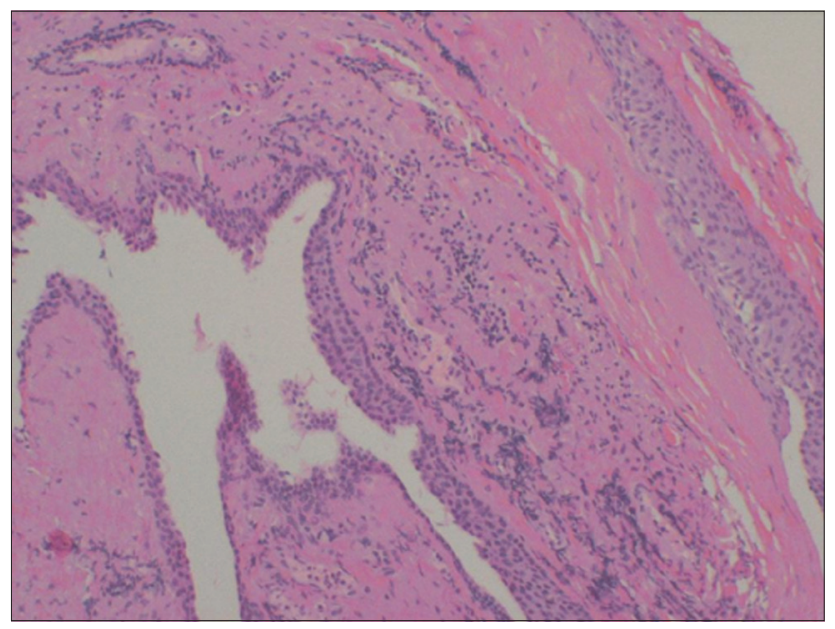

Figure 3: Hematoxylin and eosin stain 
[Downloaded free from http://www.surgicalneurologyint.com on Monday, January 28, 2013, IP: 131.193.153.56] || Click here to download free Android application fo this journal

cytokeratin-7, epithelial membrane antigen, and carcinoembryonic antigen [Figure 4]. The epithelium was nonreactive for cytokeratin-20, thyroid transcription

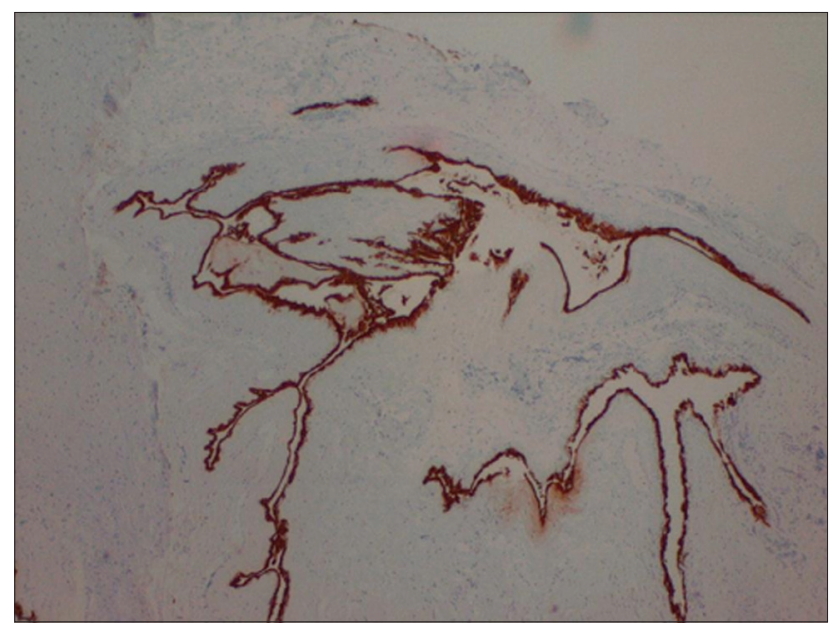

Figure 4: Cytokeratin 7 stain factor-1, and glial fibrillary acidic protein [Figure 5]. The surrounding neuroglial tissue shows strong reactivity for glial fibrillary acidic protein.

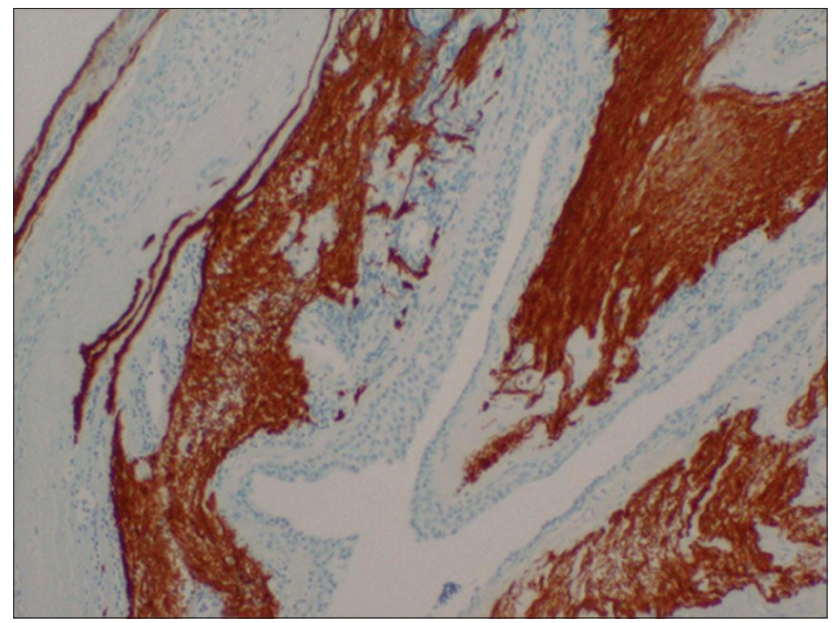

Figure 5: Glial fibrillary acidic protein stain

Table 1: Published cases of intradural neurenteric cysts $^{[1,2,10,11,14-22,24,25,27,28,30,31]}$

\begin{tabular}{|c|c|c|c|c|c|c|c|}
\hline Source & Age & Sex & Location & Treatment & $\begin{array}{c}\text { Recurrence on } \\
\text { MRI }\end{array}$ & $\begin{array}{l}\text { Follow-up } \\
\text { (months) }\end{array}$ & $\begin{array}{l}\text { New deficits on } \\
\text { last follow-up }\end{array}$ \\
\hline Rivierez (1997) & 46 & $\mathrm{~F}$ & L1-L2 & $\begin{array}{l}\text { Biopsy and cysto- } \\
\text { arachnoid shunt }\end{array}$ & No & 6 & Yes \\
\hline Reinders (2001) & 31 & $\mathrm{~F}$ & T8-T9 & Subtotal resection & No & 2 & Yes \\
\hline Rauzzino (2001) & 19 & $\mathrm{~F}$ & T12-L2 & Subtotal resection & Yes & 72 & No \\
\hline Rauzzino (2001) & 6 wks & $\mathrm{F}$ & T12-L2 & Subtotal resection & No & 84 & No \\
\hline Sharma (2001) & 24 & $\mathrm{~F}$ & L1-L2 & Subtotal resection & Yes & 60 & No \\
\hline Singal (2001) & 67 & $M$ & T7 & Total resection & Unknown & Unknown & Unknown \\
\hline Lippman (2001) & 68 & $\mathrm{~F}$ & T10-T11 & Subtotal resection & No & 1.5 & No \\
\hline Agrawal (2002) & 3 mon & $M$ & T1-T7 & Total resection & Unknown & Unknown & No \\
\hline Paolini (2002) & 28 & $\mathrm{~F}$ & T8-T9 & Subtotal resection & No & 12 & No \\
\hline De Oliveira (2005) & 6 & $\mathrm{M}$ & $\mathrm{C} 4-\mathrm{C} 7$ & Total resection & Yes & 96 & No \\
\hline De Oliveira (2005) & 6 & $\mathrm{~F}$ & C7-T1 & Total resection & No & 168 & No \\
\hline De Oliveira (2005) & 3 wks & $M$ & T10 & Total resection & No & 0.75 & Deceased \\
\hline Rotondo (2005) & 67 & $\mathrm{~F}$ & T10-T11 & Total resection & No & 3 & No \\
\hline Rotondo (2005) & 52 & $\mathrm{~F}$ & T12-L1 & Total resection & No & 12 & No \\
\hline Rotondo (2005) & 61 & $\mathrm{~F}$ & T12-L1 & Total resection & No & 6 & No \\
\hline Menezes (2006) & 6 & $M$ & $\mathrm{C} 2-\mathrm{C} 3$ & Subtotal resection & Yes & 216 & No \\
\hline Menezes (2006) & 4 & $\mathrm{~F}$ & C4-C6 & Total resection & No & 156 & No \\
\hline Menezes (2006) & 40 & M & C6 & Subtotal resection & Yes & 36 & No \\
\hline Nagi (2007) & 40 & $\mathrm{~F}$ & C3-C4 & Subtotal resection & No & 3 & No \\
\hline Muzumdar (2008) & 12 & $M$ & $\mathrm{C} 2-\mathrm{C} 3$ & Total resection & No & 36 & No \\
\hline Cai (2008) & 3 & $\mathrm{~F}$ & C7-T1 & Subtotal resection & No & 60 & No \\
\hline Takahashi (2008) & 8 & M & T5 & $\begin{array}{l}\text { Biopsy and } \\
\text { aspiration }\end{array}$ & Yes & 36 & No \\
\hline Yilmaz (2009) & 17 & $\mathrm{M}$ & T12-L1 & Subtotal resection & No & 6 & No \\
\hline Aydin (2009) & 14 wks & $\mathrm{F}$ & C4-T1 & Total resection & No & 120 & No \\
\hline Theret (2010) & 4 wks & $M$ & C6-7 & Subtotal resection & No & 24 & No \\
\hline Ziu (2010) & 39 & $M$ & T11-T12 & Total resection & Unknown & Unknown & Unknown \\
\hline Kleklamp (2011) & 50 & $M$ & C6-T1 & Total resection & Unknown & Unknown & No \\
\hline Jhawar (2012) & 3 & M & C6-T3 & Subtotal resection & Unknown & 12 & No \\
\hline Present case & 35 & $\mathrm{~F}$ & T12-L1 & Subtotal resection & No & 5 & No \\
\hline
\end{tabular}


[Downloaded free from http://www.surgicalneurologyint.com on Monday, January 28, 2013, IP: 131.193.153.56] || Click here to download free Android application f this journal

\section{DISCUSSION}

Intramedullary neurenteric cysts are thought to represent $12.2 \%$ of all neurenteric cysts. In the published pediatric literature, the cervical spine was the most common presenting location (36\%). ${ }^{[6]}$ In our review, we found the lower thoracic and thoracolumbar spine to be the most common location for intramedullary neurenteric cysts.

The treatment options for intramedullary neurenteric cysts remain controversial. Most authors advocate total resection when possible. ${ }^{[1,5,15]}$ Menezes and Traynelis recommend an anterior approach because the lesions are typically ventral to the spinal cord. ${ }^{[15]}$ De Oliveira, on the other hand, recommends a posterior approach because it is technically easier and causes fewer complications for the patient. ${ }^{[5]}$ Takahashi has published his experience with MR imaging-guided, percutaneous aspiration and believes it should be the treatment of choice, with the caveat that conventional surgery may be necessary in the future. ${ }^{[27]}$

In the current published literature, the overall recurrence rate for neurenteric cysts after surgical resection varies from $11.6 \%$ to $37 \% .^{[6,23]}$ To our knowledge, there is no published data on the recurrence rates of intramedullary neurenteric cysts. Of the 24 published cases with a followup MRI [Table 1], six (25\%) showed radiographic signs of recurrence at a mean follow up of 51 months. Four underwent a subtotal resection, one a total resection, and one a MRI-guided percutaneous aspiration. None of the patients that had a gross total resection of their cyst had a recurrence. There was one death due the respiratory complications in a 3-week-old and two patients who had new deficits on their last follow-up visit.

Tethered cord syndrome has been reported in association with neurenteric cysts. ${ }^{[3,9,7,11,15,19]}$ Spinal cord detethering is indicated in patients with progressive neurological deficits ${ }^{[13]}$ and has been shown to improve pain and neurological function in the majority of patients. ${ }^{[1,12]}$ The pathophysiology of tethered cord syndrome is believed to be a result of lack of blood flow from progressive traction. ${ }^{[29]}$ Adult onset tethered cord syndrome is thought to differ from pediatric tethered cord syndrome in that there is a lesser degree of tension on the $\operatorname{cord}^{[8]}$ and a certain "threshold" must be crossed before a patient becomes symptomatic. ${ }^{[26]}$ Given that the neurenteric cysts are slow growing lesions that cause symptoms through a compressive process, ${ }^{[23]}$ one could postulate that our patient had a previously asymptomatic tethered spinal cord that was pushed over the threshold from the progressive growth of her neurenteric cyst. We elected to detether the spinal cord prior to intramedullary dissection in the hope that this would reduce the risk for neurological deficits during the lesion resection.

\section{CONCLUSIONS}

Intramedullary neurenteric cysts are extremely rare spinal cord lesions that are benign in nature. We report a case of an intramedullary neurenteric cyst in the thorocolumbar region with an associated tethered cord. There are 29 cases in the published literature since the advent of MRI and of the cases with a follow-up MRI, the overall recurrence rate was found to be $25 \%$.

\section{ACKNOWLEDGMENTS}

The authors acknowledge Dr. Meena Gujrati for providing digital copies of the patient's pathology slides and Joanna Fleckenstein for her assistance in proof reading and editing.

\section{REFERENCES}

I. Agarwal D, Sura A, Mahapatra AK, Sharma MC. Intramedullary neurenteric cyst presenting as infantile paraplegia:A case and review. Pediatr Neurosurg 2002;37:93-6.

2. Aydin AL, Sasana M,Ucar B,Afsharian R, Ozer AF. Prenatal diagnosis of a large, cervical, intraspinal, neurenteric cyst and postnatal outcome. J Pediatr Surg 2009;44: 1835-8.

3. Bakaris S, Senoglu M,Yuksel Z, Gokce M. Lumbosacral neurenteric cyst with associated tethered cord in an adult. Clin Neuropathol 2005;24:5I-5.

4. Cai C, Shen C,YangW, Zhang Q, Hu X. Intraspinal neurenteric cysts in children. Can J Neurol Sci 2008;35:609-I5.

5. De Oliveira RS, Cinalli G, Roujeau T, Sante-Rose C, Pierre-Kahn A, Zerah $M$. Neurenteric cysts in children: 16 consecutive cases and review of the literature.J Neurosurg 2005; 103:5 I 2-23.

6. De Oliveira RS, Cinalli G, Sante-Rose C, Machado HR, Zerah M. Neurenteric cysts. In: Ozek MM, Cinalli G, Maixne WJ, editors. Spina Bifida: Management and Outcome. New York, NY: Springer; 2008. p. 465-85.

7. Freund F,Thale A, Hutzelmann A. Radiologic and histopathologic findings in a rare case of complex occult spinal dysraphism with association of a lumbar fibrolipoma, neurenteric cyst and tethered cord syndrome. Eur Radiol 1998;8:624-7.

8. Gupta SK, Khosla VK, Sharma BS, Mathuriya SN, PathakA,Tewari MK.Tethered cord syndrome in adults. Surg Neurol 1999;52:362-70.

9. Jain RS.A spinal neurenteric cyst presenting as burning feet syndrome. Int J Clin Pract 2003;57:846-7.

10. Jhawar SS, Mahore A, Goel A. Intramedullar spinal neurenteric cyst with fluid-fluid level.J Neurosurg Pediatr 2012;9:542-5.

II. Klekamp J. Tethered cord syndrome in adults. J Neurosurg Spine 20 I I; I5: 258-70.

12. Lee GY, Paradiso G, Tator CH, Gentili F, Massicotte EM, Fehlings MG. Surgical management of tethered cord syndrome in adults: Indications, techniques, and long-term outcomes in 60 patients. J Neurosurg Spine 2006;4:123-31.

13. Lew SM, Kothbauer KF.Tethered cord syndrome:An updated review. Pediatr Neurosurg 2007;43:236-48.

14. Lipmann CR,Arginteanu M, Purohit D, Naidich TP, Camins MB. Intramedullary neurenteric cysts of the spine: Case report and review of the literature. J Neurosurg 2001;94(2 Suppl):305-9.

15. Menezes AH,Traynelis VC. Spinal neurenteric cysts in the magnetic resonance imaging era. Neurosurgery 2006;58:97-105.

16. Muzumdar D, Bhatt Y, Sheth J. Intramedullary cervical neurenteric cyst mimicking an abscess. Pediatr Neurosurg 2008;44:55-6I.

17. Nagi S, Ghorbel D, Drissi C, Maatallah Y, Hammami N, Hamouda M. Intramedullary neurenteric cyst without concurrent malformation. Australas Radiol 2007;5I Spec No.:BI4-7.

18. Paolini S, Ciappetta P,Domenicucci M, Guiducci A. Intramedullary neurenteric cyst with a false mural nodule: Case report. Neurosurgery 2003;52:243-6.

19 Rauzzino MJ, Tubbs RS, Alexander E 3rd, Grabb PA, Oakes WJ. Spinal 
[Downloaded free from http://www.surgicalneurologyint.com on Monday, January 28, 2013, IP: 131.193.153.56] || Click here to download free Android application fo this journal

Surgical Neurology International 20 I 2, 3:80

neurenteric cysts and their relation to more common aspects of occult spinal dysraphism. Neurosurg Focus 2001;10:e2.

20 Reinders JW, Wesseling P, Hilkens PH. Intramedullary enterogenous cyst presenting with spastic paraparesis during two consecutive pregnancies: $\mathrm{A}$ case report. J Neurol Neurosurg Psychiatry 200I;71:528-30.

21. Riviérez M, Buisson G, Kujas M, Ridarch A, Mignon E, Jouannelle A, et al. Intramedullary neurenteric cyst without any associated malformation: One case evaluated by RMI and electron microscopic study.Acta Neurochir (Wien) 1997; 139:887-90.

22. Rotondo M, D'Avanzo R, Natale M, Pasqualetto L, Bocchetti A, Agozzino L, et al. Intramedullary neurenteric cysts of the spine: Report of three cases. J Neurosurg Spine 2005;2:372-6.

23. Savage JJ, Casey JN, McNeill IT, Sherman JH. Neurenteric cysts of the spine. J Craniovertebr Junction Spine 20 I 0; 1:58-63.

24. Sharma RR, Ravi RR, Gurusinghe NT, Coutinho C, Mahapatra AK, Sousa J, et al. Cranio-spinal enterogenous cysts: Clinico-radiological analysis in a series of ten cases. J Clin Neurosci 2001;8:133-9.

25. Singhal BS, Parakh HN, Ursekar M, Deopujari CE, Manghani DK. Intramedullary neurenteric cyst in mid thoracic spine in an adult: A case report. Neurol http://www.surgicalneurologyint.com/content/3/ //80

India 2001;49:302-4.

26. Stetler WR Jr, Park P, Sullivan S. Pathophysiology of adult tethered cord syndrome: Review of the literature. Neurosurg Focus 2010;29:E2.

27. Takahashi S, Morikawa S, SaruhashiY, Matsusue Y, Kawakami M. Percutaneous transthoracic fenestration of an intramedullary neurenteric cyst in the thoracic spine with intraoperative magnetic resonance image navigation and thoracoscopy.J Neurosurg Spine 2008;9:488-92.

28. Theret E, Litre CF, Lefebvre F, Eap C, Duntze J, Scherpereel B, et al. Huge intramedullar neurenteric cyst with intrathoracic development in a I monthold boy: Excision though the anterior approach.A case report and review of the literature.Acta Neurochir (Wien) 2010;152:48I-3.

29. Yamada S, Won DJ, Pezeshkpour G, Yamada BS, Yamada SM, Siddiqi J, et al. Pathophysiology of tethered cord syndrome and similar complex disorders. Neurosurg Focus 2007;23:E6.

30. Yilmaz C, Sulsen S, Sonmez E, Ozger O, Unlukaplan M, Caner H. Intramedullary bronchogenic cyst of the conus medullaris.J Neurosurg Spine 2009; I 1:477-9.

31. Ziu M,Vibhute P,Vecil GG, Henry J. Isolated spinal neurenteric cyst presenting as intramedullary calcified cystic mass on imaging studies: Case report and review of literature. Neuroradiology 20 10;52: I 19-23. 